\title{
Business Ethics. Teaching and Learning
}

Prof. Wojciech Gasparski Ph.D.

Prof. Anna Lewicka-Strzałecka Ph.D.

Dariusz Bąk Ph.D.

Bolesław Rok Ph.D. | Business Ethics Centre Kozminski University and the Institute of Philosophy and Sociology of the Polish Academy of Science Warsaw | cebi@kozminski.edu.pl

All Sisyphus' silent joy is contained therein. His fate belongs to him, his rock is his thing. (...) Each atom of that stone, each mineral flake of that night-filled mountain, in itself forms a world. The struggle itself toward the heights is enough to fill a man's heart. One must imagine Sisyphus happy.

Albert Camus, The Myth of Sisyphus, transl. by Justin O’Brien

\section{Abstract}

\section{Purpose}

Recapitulation of educational experiences in the field of business ethics. Identification of risks and opportunities referring to ethical education, both on academic and professional levels. 


\section{Methodology}

A broad description with more profound analysis of chosen issues.

\section{Findings}

The essay gathers experiences from the field of business ethics education on different levels: organization and academic as well as postgraduate. It shows a specificity at each level, especially the differences between assumptions, and then evaluates efficiency. It underlines the didactic and formation aspects of business ethics. It enables one to follow the changes within business ethics as an educational subject with aims and methods. In the end, the changes lead to presenting business ethics as an efficient instrument of forming desirable attitudes and standards in organizations.

\section{Originality}

A presentation of the main problems of ethical education gives an opportunity to improve programs and methods in the area of education. The essay presents the ways of adapting the educational offer to the expectations of society as well as to market requirements.

Key words: ethics, education, ethical programs, ethical standards

\section{JEL: M19}

\section{| Introduction}

Dealing with ethics, and business ethics in particular, recalls Sisyphus' toil of repeated efforts to persuade others and convince oneself that this is not an oxymoron. Numerous scandals, irresponsibility of economic theorists (Aldred 2008), a financial crisis (Dembiński 2011), mobbing and many other bad practices are often cited by sceptics who doubt that it is possible for education in the field of business ethics to influence attitudes, decisions and conduct of the actors playing on the business stage.

The Business Ethics Centre, a joint unit of Kozminski University and the Institute of Philosophy and Sociology of the Polish Academy of Science, tackles the issue of education in the field of business ethics for the fourth time. The first conference on business ethics as a university course was held in 2000 (Gasparski, Lewicka-Strzałecka 2001). A Polish daily Rzeczpospolita wrote about the conference (4 April 2001): 
A concept of business ethics is gaining a broader right of citizenship in discussions on the ongoing economic transformation in Poland. Recently, education in this field becomes in Poland a distinct academic specialty undertaken at many universities.

After more than a decade since that event, the problems discussed during the conference are still topical. The conclusion that was included in the summary of the conference is also a live issue:

A critical discussion of current education and exchange of experience will enrich the repertoire of curricula and teaching methods (...), aimed not only at education but also at shaping the attitudes of students of universities in which the course is offered (Gasparski, LewickaStrzałecka 2001: 6).

In 2007 we organized a conference on responsible management education (Gasparski 2008). When sending invitations to participate in it, we wrote:

Issues related to the education of practitioners are becoming important in a knowledge society. Primarily, this applies to management education which is situated on the borderline of economics, sociology, psychology, information technology and other disciplines that scientific knowledge is divided into. However, the division (dispersion) of scientific knowledge should not be transferred to the practice which uses that knowledge, as practice needs to be perceived as a whole. Wise physicians say one should 'treat the patient, not this or that organ.' This requires skilful use of the results of numerous analyses - on which knowledge from the aforementioned disciplines is based - to prepare the syntheses necessary to develop appropriate practical solutions.

In Sarah Murray's paper "A degree of ethical leadership" published in the Financial Times in January 14, 2007, the writer pointed to the differences between the attitude that is increasingly being adopted as part of responsible business. It comprises namely the commitment to fighting corruption, sustainable development, compliance with employee treatment standards, and environmental standards and social standards. It also includes the attitude of university level schools to these issues and their level of commitment to what is referred to as "responsible business/management education."

The article was published in connection with the growing willingness of the academic community to get together with the business community and join the UN Secretary General's initiative known as the Global Compact for responsible business activity in a globalized world. It has been clearly stated that there is a need to draw up a set of principles for responsible education for business. Accordingly, "The Six Principles for Responsible Management Education” were announced at the Global Compact Leaders World Summit held in Geneva on 5 July 2007 in cooperation with the Caux Round Table Global Dialogue.

Adopting these principles for practical application at Polish universities in educating management specialists (managers) should be obvious. Adjusting curricula and everyday school operations to the principles is a management education challenge worthy of the country that declares its 
commitment to becoming a knowledge-based society and to practicing responsible business. This requires discussion among academics of Polish universities educating business people and managers of various specialties. With this in mind, the Business Ethics Centre organized in association with the Caux Round Table Polska a conference on "Responsible Management Education."

The issue of education and business ethics was undertaken again in 2009 at the Polish Congress of Business Ethics and Corporate Social Responsibility organized in connection with the decennary of the Business Ethics Centre. The panel discussion on that topic was preceded by a session "All I need to know about ethics and corporate social responsibility (CSR) I learned at university." During the session, alumni, undergraduates, graduates, and doctoral students presented their positions on problems of teaching business ethics and CSR at Polish universities. The debate was concluded with the following statement:

Discussants noted the opportunities for a potential use of ethical - theoretical - knowledge in practice, its positive impact on attitudes and conduct of young people, particularly through good examples (cases). They also put forward critical arguments concerning, among others, the lack of: (i) education in some schools, (ii) the teaching staff, (iii) literature, (iv) coherence between the knowledge presented and the functioning of the university. (...) In many cases a conflict between ethical values and economic values is reduced to one type, analyzed from one perspective, no relevant tools to solve problems are provided, different theories, concepts, interpretations are not discussed and instead one model of problem analysis is applied.

(Andrejczuk et al. 2010: 235-236).

Panellists pointed to a stringent time framework provided for business ethics courses. There were some basic issues that were tackled during the panel debate:

- Should teaching of business ethics be compulsory?

- Should business ethics be not only a separate subject but also an element of practical disciplines preparing for the profession of a manager?

- What methods of teaching of business ethics should be used in circumstances of limited hours devoted by universities for this course?

- What foreign models should be used?

- Should CSR be taught as a separate course or should it form part of BE (business ethics) or vice versa?

- Should postgraduate studies at universities and trainings in companies be introduced/continued and if yes, what kind of studies and trainings should be offered?

The answers to these questions are presented in a special chapter of the book (Gasparski, Rok, Lewicka-Strzałecka, Bąk 2010: 189-236).

Referring to the question of foreign experience, we will begin this article with comments on the teaching of business ethics at American universities. American business ethicists are probably the 
most experienced group in two senses of this word: it has taught business ethics the longest, and is experiencing the consequences of business conduct that are far from those of best practices.

\section{Do you comprehend the ethics?}

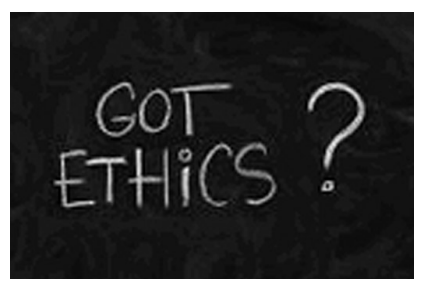

"Got Ethics?" are the words written in chalk on a blackboard. That school graffiti adorns the front cover of the collective work "Towards Assessing Business Ethics Education" dedicated to business ethics education in the United States (Swanson \& Fisher 2011). One should, in the wake of this question, ask whether the American business ethics education can be seen as a success or a failure in retrospective view of the recent 2007-2009 financial crisis. If a success, it means that it could have been worse than described by the author, also an American, of another book "Business Fairy Tales: Grim Realities of Fictitious Financial Reporting” (Jackson 2008). If a failure, one must agree with Charles Ferguson, the author of a film "Inside Job"1 telling the inside story about the crisis, and repeated in another American book "Enough" (Bogle 2009). One can then find out whether and how business ethics education is evaluated by authors of the articles in the aforementioned American collective work. This assessment can serve as a background for the evaluation of teaching and learning of business ethics in Poland modelled largely on the American experience.

The editors of the American collective work remind us that business ethics has been discussed for a long time. Numerous publications, conferences, lectures and seminars testify to the fact that it certainly gained the status of an academic discipline many years ago. Nevertheless, they immediately indicate that a current interest in evaluating business ethics education was aroused by scandals putting into doubt the reputation of business schools. The authors of articles published in this book indicate the kind of an educational triad on which the effectiveness of business ethics education depends. The elements of the triad are:

1) a compulsory lecture on basics of business ethics;

2) teaching of ethics elements dispersed in different parts of the curriculum in business schools in such a way that these elements form a coherent whole; and

3) guest lectures by practitioners, projects, endowed chairs and professor positions.

\footnotetext{
1 "An Oscar-winning film is the first video footage documenting the shocking truth about the inside story of the economic crisis of 2008. The global collapse of financial markets which made losses of over 20 trillion dollars, led as a result to the loss of jobs and houses by millions of people. Thanks to the large-scale and thorough research activities and interviews conducted with key players on financial markets, politicians and journalists, the film shows the development of speculative financial transactions and the financial industry behind it. It also sheds light on the mutual relations and mechanisms that led to the corruption of political, regulatory and scientific world's actions." [http://www.filmweb. pl/film/lnside + Job-2010-573864; 26.08.2011].
} 
Unfortunately, the authors conclude that a compulsory lecture as a condition of graduation of business school students has been resisted by both the universities themselves and accreditation agencies. Attempting to answer the question as to the reasons for such a situation, the American business ethicists respond that it is rooted in the underestimation of the ethical issues by deans engaged in acquiring financial resources, care for the satisfaction of graduates and seeking to maintain their positions. Accreditation institutes, dominated by the environment of business school deans, act similarly. Dotting the i's and crossing the t's, one would say that the cause lies in the specific ethics of college administrators.

Resistance to a fully fledged business ethics education leads, as the Americans write, to the need to "rediscover the wheel" increases the risk of insufficient fulfilment of students' needs and an incorrect assessment of learning outcomes. The authors state that accreditation agencies came to a dead end because on the one hand, they demand compliance with high standards of business ethics education. On the other hand, they do not act to ensure a proper curriculum of business ethics education as a course and evaluate the education results by indicating benchmarks. This situation results in the level of instruction depending on the university administration, academic staff, students, alumni and other community members cooperating with a particular institution. At this juncture, it is also worth pointing out what Polish students expect from a course in Business Ethics (Box).

\section{What do students expect from "business ethics"?} Basics

a) Do ethics and business go hand in hand?

b) Are there any "mechanisms" hidden in the concept of "business ethics" and what they are?

Values

c) Is morality responsible for our actions and conduct?

d) Why do people behave unethically, what drives them?

e) How does public ethics affect business ethics?

f) What kind of values is the business environment guided by?

g) Do businesses act ethically in fact?

Principles

h) What ethical principles (standards) is business guided by?

i) What moral principles should be followed by employees of organizations?

j) What principles should be followed by high-level managers?

k) What decisions (examples) are ethically good and what are bad?

I) What arguments does business ethics provide?

\section{Limits}

m) How to speak partial truth without cheating?

n) How far can we go to help protect the organization which we are members of?

o) What should one be driven by when taking decisions if they refer to difficult situations: morality, his own good, interests of his closest ones?

p) What unethical behavior in business (scandals) were presented in the media?

Conduct

q) How to behave ethically?

r) How to make ethical decisions?

s) How to ensure the best results for stakeholders (interested parties)?

t) How to behave in business contacts, for example, during the negotiations?

u) How to persuade others to ethical business conduct?

v) How to recognize ethical business partners?

w) How to present one's morality without causing stress and conflict in the environment?

x) How to manage a company so that employees behave ethically in the wake of the leader?

y) How to deal with one's potential subordinates?

z) How to influence the organization to develop a conscious and moral conduct of its members? 
The existing state of affairs induces American business ethicists to search for Renaissance ways (as they write) of providing and evaluating business ethics education. Therefore, they indicate the principles of responsible management education, which is known to the Polish society of business ethicists and the environment of persons responsible for curriculums at Polish universities since their introduction by the UN Office of Global Compact (Gasparski 2008a; Gasparski 2008b). These principles, declaratively known, did not significantly affect the modification of specific curricula in business schools. The American authors therefore indicate the following issues should be addressed by universities:

- How is business ethics essentially perceived at a specific university?

- How is ethical competence of trainees assessed?

- What is the assessment made for?

One may fear that the answers to these questions, as the authors state, suggests that universities do not do enough to strengthen and consolidate the pro-social attitudes of students to which many students aspire (op. cit.: 9). It is necessary, the Americans propose, to conduct business ethics classes as an interdisciplinary course designed to encourage teamwork by active learning experience (ibidem).

Just as it was done previously, it is worth emphasizing a Polish example of interim projects inducing students to teamwork, introduced in Kozminski University a long time ago:

Interim projects consist in preparation of reports on the state of ethics of selected organizations/companies by teams consisting of several persons (not more than 10 persons). Teams are formed by students at the first lecture according to their interest in a particular business sector or location; building a team requires the approval of the lecturer. The team, following the guidelines in the 'Tools package ${ }^{2}$ carries out an ethical audit of such organizations that they consider representative of the selected business sector/location. The audit should be followed by preparation of a report indicating the ethical content of an organization and giving recommendations for use by companies whose ethical dimension was analyzed as well as recommendations for other companies in a particular business sector/location. Preparation of the report and its presentation is the basis for the oral part of the examination

(W. Gasparski, A guide to the course "Elements of Business Ethics" taught at Kozminski University).

The American authors point to the need for action to transform business schools into socially responsible institutions according to the principles of responsible management education. They refer to BGP Global 100 as a survey and ranking of universities preparing students, especially in MBA programs and thus business leaders, to take into account social and environmental dimensions in the activities of companies. BGP stands for the Beyond Grey Pinstripes ranking (meaning

2 J. Cieślik, Gasparski W, Ethical Firm: A tools kit for implementing ethical standards in sme (in Polish), Kozminski University, Warsaw 
literally beyond the grey pinstripes of ordinary ranking tables), reporting business schools that integrate social and environmental education issues into their programs and scientific research. The ranking came into existence as a derivative of the program of the Aspen Institute Business and Society with these aims:

A. Promoting innovation in the training of the business staff;

B. Providing students with knowledge about the impact of management on a social and natural environment;

C. Increasing the importance of this issue in curriculums;

D. Drawing attention of school candidates to the fact that the skills in the field of social and ecological aspects of an economic activity are an important component of business decisionmaking;

E. Indicating the best education programs, research and supporting (extracurricular) activities;

F. Supporting the language of discourse on social issues among students, the academic staff, administration and business leaders.

In a published statement of 100 universities with the highest BGP ratings, there were indicated universities in the following countries: Australia (2), Belgium (1), Denmark (1), Philippines (1), Finland (1), France (3), Spain (3), the Netherlands (1), Canada (7), South Korea (1), Mexico (1), South Africa (1), Slovenia (1), Switzerland (1), USA. (68), Venezuela (1), United Kingdom (6) (Martell \& Castiňeira 2011: 104-118).

It would be good to carry out a similar analysis of Polish business schools to see whether and to what extent the universities themselves understand business ethics and contribute to its understanding by their students, the future business leaders. One should repeat after the American authors that knowledge of the moral dimension testifies of professionalism (Swanson \& Fisher 2011: 10) of a trade conducted and the function performed.

However, it is not only about the ordinary teaching and everyday business. The business ethics education also has a broader context because the moral dimension of an economic activity is fundamentally significant. Mario Vargas Llosa, a Nobel Prize laureate, draws attention to this question saying:

Capitalism is in a deep spiritual and moral crisis. Without a moral, secular or religious dimension, capitalism is falling apart. All great theorists, starting from Adam Smith, wrote about it. Justification of a system based on free entrepreneurship and political freedom is primarily a moral one. Capitalism without morality is only a vulgar practice which ends with such disasters as the present one. (...) Tolerance for corruption and greed above all is a rape of culture. (...) Profit and success of a private business are legitimate if they benefit the whole community. If their effect is only the profit of an owner and other potentates, the system does not work (Gazeta Wyborcza, No. 253 (7374): 18). 


\section{| Business ethics as an academic course}

Since the moment when business ethics began its career as an academic discipline, discussions of two groups of issues have become natural. The first group concerns the teaching of business ethics, and especially the difficulties with the reception of a humanist course usually carried out in economics and related fields. The passage of time and development of teaching methods have changed little in this regard. Ethical issues are no longer exotic in business schools but they still face the barrier of the competence of students. It is impossible not to agree with the observation made by Ewa Chmielecka, expressed during a conference on good manners in academic education, and referring to the student profile in these fields of studies:

I come to class and students sit angry at the fact that they will be wasting time on things that they assumed faded into oblivion along with the secondary school (...) Most of the students have fundamental deficiencies in the humanities and I do not mean unfamiliarity with the literature canon or understanding of history. Most of them cannot answer the question what humanities is and why it is cultivated. Most often their axiological argument ends with the values and actions of an instrumental character - interests, showing inability to understand autotelic values. And they appreciate the economy for its utility nature.

(Kloc, Chmielecka 2004: 159).

The second group of issues relates to the specificity of the course itself and is an attempt to define its starting point, methods and expectations. Business ethics is a philosophical discipline, and as such it is doomed to continually define anew its assumptions. As noted by a contemporary sociologist of morality, P. Pharo:

Individual civic systems of morality, with their different and partly contradictory philosophical, religious and cultural contexts, still thus permeate a contemporary ethical debate, even if the scientific knowledge that supports this debate offers a basically standardized and universally accepted framework for reflection.

(Pharo 2008: 37).

This is not an allegation but rather a statement of fact that ethics, as a philosophical discipline, is evidence of an ongoing intellectual effort aimed at defining criteria for living a good, decent and happy life. An undoubted benefit of business ethics is its empowerment and the ability to conduct an internal dialogue. This dialogue is a value in itself because in spite of ambiguous decisions, it is the space for shaping ethical sensitivity of its participants, especially students. Discussing a number of often conflicting ethical conceptions can indeed lead to their relativity. However, this has two tangible and positive results.

The first result is expansion of the conceptual and linguistic competence of students. The close relationship between the stock of knowledge and the normative system is noted by Maria Ossowska (see Ossowska 2005: 72-76). The perception of the world depends on the language that descri- 
bes it. In this case, the efficiency of the language apparatus and the knowledge possessed directly influences the quality of moral judgments and the ability to justify them.

The second result is avoiding attitudes and beliefs about the nature of a dogmatic character. These are beliefs built certainly in the sphere of a subjective world view. However, the appearance of objectivity that accompanies them is usually anchored in some kind of scientific speculation. It should be noted that many of the disciplines in economic fields of studies adopt certain implicit ethical assumptions and promotes them within their own discipline in a mechanical and incogitant manner. F. Fukuyama, when analyzing this phenomenon, refers to the interesting research:

As part of a certain sociological experiment in large groups of university students, there were distributed chips that each participant could exchange for money. Following the exchange, the students had to decide whether they would keep the amount payable to them or give it out to a common pool for distribution among the whole group. It turned out that from forty to sixty percent of the respondents were guided by altruistic motives. An inglorious exception was a group of students of the last year of economics

(Fukuyama 1997: 29).

The conclusions of the experiment are ambiguous. Advanced students of economics appear here as the custodians of the truth inaccessible to others. They know better, see more clearly, and do not allow themselves to get carried away with a sentimental illusion. An alternative conclusion is the recognition of the importance of intellectual training experienced by economic graduates that, according to the assumptions of classical economics, forces them to perceive market participants as individuals making rational choices, with a simultaneous assumption that rationality is the ability to identify and maximize the so-called "self interest."

What seems to distinguish ethics, including business ethics, is the teaching and formation nature. Such classes are not limited merely to sharing knowledge but they also create certain attitudes. An undisputed transfer of knowledge from a teacher to a student in this case is replaced with dialogue methods. The student has the right to disagree and certainly to initiate discussion with the teacher. Such a discussion has not only its cognitive value. Numerous studies have confirmed what Anna Lewicka-Strzałecka comments by pointing to positive and negative effects of the phenomenon that:

- During the early maturity of man (at ages of 20-30), there are significant changes in the strategies for solving moral problems;

- Methods to improve the level of moral reasoning, consisting in group discussion of moral problems, especially among a group of persons remaining with one another in constant contact, can change their way of evaluating;

- There could be a shift of opinion and choices towards those that prevail or are the most widely discussed, i.e. the effect of group polarization (Lewicka-Strzałecka 2001: 124).

In this context, one can point to two main groups of tasks that are to be dealt with by business ethics, and that are carried out in various proportions in all of these courses. The first group is 
functional and assumes providing students with knowledge about the current set of tools that serve for development of ethical policy of an organization. The package usually contains information on the meaning and structure of the codes of conduct and ways of their implementation, trainings, ethics audit, compliance policy and the CSR strategy. The reception of such issues is not usually a problem. A pragmatic nature of the ethics policy is perceived by students as consistent with the general requirements of "rationality." Arguments relating to the optimization of costs, avoidance or management of a conflict of interest, losses related to an "unethical" conduct are compelling. What is more, they meet the expectations of employers and the needs of the market, as evidenced by the growing popularity of postgraduate studies in CSR and compliance.

The second group of tasks refers to the creation of a widely understood humanistic culture. Having contact with the intellectual heritage of one's own cultural background has an added value. What seems more important is drawing an axiological horizon constituting the background of decisions taken. It is normal that for a modern student, filled with the success syndrome, these are pragmatic values that play a leading role. At the same time, all roads pointing to the realm of "being" rather than "having" are antagonized and depreciated. Meanwhile, as noted by Andrzej Sztylka:

... the humanistic reality is not opposed to - out of the assumption itself - the pragmatic reality but it actually overlaps with it, interacts with it, supports it in the sense giving it a human shape. Showing a human sense of a business activity, naturalness of human desire to obtain humanistic benefits and fulfilment in a well-organized and created work strengthens and protects it from degeneration, anti-human tendencies and humiliation

(Sztylka 1999: 15).

The appropriate interpretation of the world of values is capable of showing the richness of human choices with distinguishing of autotelic purposes, with respect to which the economic values play only an instrumental function. A full understanding of the axiological order positions the humanities, philosophy and ethics in relation to other sciences, and also makes it clear what it means to be a responsible subject of one's own actions. It also allows one to define the scope of autonomy, causative power, freedom and distance from a mercantile view of the world. Dealing with the humanistic culture is also a contribution to an in-depth analysis of individual hierarchy of values and adoption of an attitude that is open to dialogue. Ewa Nowak and Karolina M. Cern, when describing the concept of moral education according to Kohlberg and Linda, indicated the following effects:

- Gaining and deepening awareness of one's own moral principles;

- Paying close attention to the facts and circumstances present in a particular situation;

- Differentiating one's own moral principles in terms of importance and rightness;

- Finding more general, supreme moral principles in the event of a conflict between two equally strong moral principles;

- Articulation of one's own moral principles in a social context (even if my friends are of a different opinion than I am), i.e. moral courage; 
- Ability to listen to the arguments of the opposing party;

- Solving of conflicts of interest with the exception of violence, but through a rational discourse;

- Learning that the "opponent" is to be respected because it represents an instance verifying one's own moral position (Nowak, Cern 2008: 387).

\section{| Ethics education in businesses ${ }^{3}$}

Ethics education is not completed at the academic stage since it is continued in the form of ethics programs that companies, especially the U.S. ones, introduce in their practice. The purpose of these programs, aimed at both managers and the general staff, is to prevent losses being suffered by the company. These consist of tarnished reputation, reduced competitiveness and demoralisation of staff, as well as certain financial losses caused by the abuse of workers. An important incentive for U.S. companies to introduce ethics programs, which are costly ventures, are the legal regulations. Systematic studies of these programs carried out by specialized centres indicate their effectiveness, both from the point of view of the company and in the broader social context. However, an analysis of their impact on the moral attitudes of employees leads to less satisfactory conclusions.

Ethics programs implemented by U.S. companies are a subject of periodic surveys conducted by the Ethics Resource Centre ${ }^{4}$. Since 1994, the nationwide survey has been conducted addressed at employees at all business levels, showing how they perceive individual elements of ethics programs and how they assess the ethical culture of their companies. Studies have a consistent character and are repeated every two years. They show among other things that fraud and unethical conduct are observed much less frequently in organizations pursuing comprehensive and formalized ethics programs. These programs significantly reduce the pressure felt by employees to engage in unethical projects, reduce the number of observed acts of fraud and thus reduce the need to signal them.

According to the Open Compliance Ethics Group, those companies that have well-functioning ethics programs do not experience scandals that ruin their reputation. This is confirmed by empirical data showing that no company that consistently implements an ethics program has been affected by a serious scandal in the last 5 years (True et al. 2005).

Nevertheless, it is worth asking whether ethics programs influence deeper ethical attitudes of people, or whether their effects are significant only at the behavioural level. Stansbury and Barry (2007) put forward the thesis that ethics programs, especially those based on coercion of certain actions, may reduce the motivation of managers and employees to ethical reflection and limit

3 More on this topic in: Lewicka-Strzałecka (2010).

4 http://www.ethics.org/. 
their ability to recognize ethical issues, analyze and resolve them. Rigid and detailed procedures for dealing with situations of moral choices do not allow people to develop an ability to make moral judgments, especially in unusual or new circumstances, and morality itself is reduced to obedience to standards contained in the codes. The authors mentioned see the negative side of ethics programs in the form of three threats which they define as the spectre of indoctrination, the politicization of ethics and the atrophy of ethical competence.

The threat of indoctrination occurs in connection with systematic and organized instilment of values accepted by the company in workers, and constituting an important goal of ethics programs. Such an action promotes closing of the mind to "those issues which are fundamentally open, and the inability to imagine things as they are not, imprisons the human being in the world of things as they are" (Laura 1983). Indoctrination inhibits moral imagination and restricts potential criticism of the system of values that is instilled in employees. Its negative side is not imposing a wrong value system onto an individual (since it is difficult to indicate the "right" system). It is preventing people from making ethical reflection, with the deprivation of an opportunity to respond to a different value system. The danger of indoctrination is not because some values are instilled, but in the result that their free interpretation and criticism is not allowed, which infringes the moral autonomy of the individual and weakens a collective potential to make a change.

Indoctrination may face passive resistance consisting of a failure to accept values promoted by the ethics program. Values can be rejected not because of themselves but because employees recognize that the mere manner of promoting them restricts their freedom of action and freedom of thought. Passive resistance may have negative consequences for ethics programs. Constant surveillance is a threat to a sense of freedom (Brehm, Brehm 1981). For example, an incidental request made by the manager to disclose a thief may be more effective than demanding workers to constantly track their colleagues and always inform about observed abuses, as the latter creates a greater resistance to denounce. If values promoted by the ethical program are similar to the values shared by employees, a sense of disturbed freedom is small; but if they are significantly different, this feeling may be significant with substantial resistance. The values that are linked only to work carried out are a source of lower pressure than the values that affect the lifestyles of employees outside the workplace. For example, banning them from smoking or drinking alcohol in the private sphere out of a concern for health may meet with a strong aversion.

The second threat associated with the idea of formalizing ethical standards designed to lead to their internalization by employees is a kind of politicization of ethics. It is a perversion of this idea consisting of treatment of ethical programs as a useful instrument in internal competitions. The politicization of ethics in a company means that ethics programs are conducive to the expansion of managers' powers and can be used simultaneously to remove the board's responsibility for irregularities occurring in a company. The study of 10,000 employees from six companies showed that if ethics programs are perceived by them as ways of managers' acquittal, the ten- 
dency of employees to act in accordance with the standards of the company and the willingness to disclose abuse is reduced (Trevino et al. 1999). If board members do not respect elementary principles of respect, contained in the company's code of conduct that workers must obligate themselves to in writing, it brings about contestation to the very idea of ethics programs.

If the company does not have consensus on its objectives and the balance of power, an ethics program can be treated either as a way to constitute a new ethos or a means of combating the opposition and playing one's own cards. This occurs first when the process of transforming the company to changing conditions raises an inevitable internal conflict whose solution requires a redefinition of certain objectives and values charted by an ethics program. In the latter case, an ethics program is seen as an instrument for coercively disciplining employees and serving goals that they do not accept.

The third threat of ethics programs with a high level of detail and stringency, to which Stansbury and Barry (2007) draw attention, is an atrophy of moral competence. A peculiar moral instruction may decrease rather than increase the skill of the individual to identify and resolve ethical dilemmas. This does not have great significance in simple and repetitive cases for which algorithms of ethical choices can be developed, but it is risky at the moment of making difficult ethical decisions entangled in complex organizational processes. Strict control of all tasks performed by workers reduces their ability to cope with new situations, while liberal control is good for shaping a wider understanding of the activities of the company, which turns out to be useful in non-standard cases.

Many codes of conduct provide instructions in simple situations and suggest seeking advice of ethics officers in more difficult cases. Although this suggestion seems to be promising because it releases persons from decision-making and shifts responsibility onto officers, it may be unrealistic. Employees may be reluctant to entrust the affairs of their inner circle to third parties and may not be able to wait for the solution of the problem that needs the solution immediately. They may also be afraid to ask for advice in a form leaving a trace, e.g. upon a document. In turn, those employees who benefit from such solutions may not develop their skills of moral judgment, and such atrophy of competence makes them vulnerable in situations where there is no time to seek advice from an expert. Such situations can be partially mitigated by the possibility of using an anonymous "hotline" (Joseph 2003) or similar channels for advice given by an ethics board, which would consist more in relating conditions for certain decision-making than in giving ready-made solutions.

An institutionalized system of support for making ethical decisions fosters a moral hazard since workers and lower-level managers avoid resolving ethical issues with a feeling that all difficult decisions should be taken at a higher level. Strict formalization of an ethical decision-making process makes it difficult for a decision maker to identify himself with its contents because his work involves only a small part and he is not able to cover the whole and to imagine alternatives. 


\section{Training in the field of ethics and corporate responsibility in postgraduate studies}

Postgraduate studies are a form of professional studies aimed at preparing graduates for the best performance of a specific function within the company. Persons who undertake postgraduate studies in ethics and corporate responsibility (CSR) intend primarily to apply for one of three positions: ethics spokesman, social responsibility manager, and sustainable development manager. There is also a rather sparse group of those who wish simply to better understand broad issues concerning the role of business in society and use this knowledge possibly later in their work in non-governmental organizations (NGOs), public institutions, and cross-sectoral projects funded from European grants. In the case of work in business, the names of these positions may vary depending on the organizational structure of the company. Such a person does not always fulfil their obligations in a managerial position; it is sometimes a higher position, e.g. board attorney, or a lower position, e.g. a specialist. However, fulfilling this function always involves the need to coordinate different areas of management and implementation of internal projects with representatives of other departments, or in case of external projects, with representatives of various stakeholder groups.

Such positions have existed in companies operating in the Polish market only recently. It is estimated that five years ago, there were not more than twenty people serving in positions of this type, whereas now there are about 200 of them. Observing the rapid growth of the market, it appears likely that in the next few years this number may increase to one thousand. Thus, this is a very fast growing job market. It is also worth noting that in some of the largest enterprises, these functions are performed by formal teams of several persons or by a few people with specifically defined tasks located in different departments. People involved in business ethics and responsibility often come from internal recruitment, and this is their opportunity for professional development. However, this is usually accompanied by an urgent need to supplement their knowledge and skills. This is a big challenge, especially since in Polish conditions we observe large variations among these people in terms of their initial education and professional training and experience. There have been no studies of this professional group yet, and there is no professional association for these people. However, observation shows that most often these are people who have previously been involved in internal or external corporate communications and who have merely a few years' professional experience. Furthermore, this is not a homogeneous group and may include persons with legal, sociological, psychological or environmental protection education. A significant group is also composed of those who have worked for some time in NGOs.

Since the majority of postgraduate students of this kind already have several years' professional experience, they usually did not have the opportunity to participate in lectures on ethics and responsibility during their courses leading to a master degree. This area is therefore new to them, although by virtue of professional interests they already have some knowledge and practical skills and enthusiasm, which is extremely valuable. However, this knowledge is often based 
on stereotypical notions from journal articles published in widely available media, and also on examples disseminated by other companies or NGO's in Poland and abroad. It also happens that the enthusiasm, or even idealism, of some students collides with a sense of impossibility (for different reasons) to make any changes in the functioning of businesses, expressed by those who have already dealt directly with such restrictions in their companies.

Full-time, two semester post-graduate studies in the field of corporate responsibility is a novelty on the Polish market. Two editions of studies in this area took place at Tischner European University in Cracow with financing from a project grant. Following the end of the grant, however, the next editions were not organized. One edition of these studies took place at the Warsaw University of Life Sciences but was not continued, either. Several higher schools in different cities presented an offer of new postgraduate studies in corporate social responsibility, but they did not meet with sufficient interest from potential students. Only the postgraduate program "CSR: Responsible Business Strategy," coordinated by the Business Ethics Centre and PwC, have been conducted continuously for three years at Kozminski University. In the next three editions, they covered a group of more than ninety students.

It can be assumed on this basis that the preparation of a curriculum that would meet market expectations as well as expectations of potential students is a major challenge in the Polish context. Market expectations are important primarily because in most cases, these are companies that pay for such postgraduate studies for their employees, in whole or in part. Expectations of students are more diverse, however, and they mainly concern the possibility of preparing oneself to perform one of the three aforementioned functions in the near future. Vocational studies for people working full-time are associated with the need to pursue studies on non-working days, mainly on weekends. Studies do not provide a guarantee of finding employment, or at least of further professional development in a chosen field. It seems that an appropriate curriculum has a key importance here.

\section{Building a PRACA curriculum for postgraduate studies}

What does or should a curriculum for postgraduate studies "CSR: Responsible Business Strategy" look like? It is aimed at supplementing knowledge in the scope of shaping a strategy of ethical and responsible business. It also has acquisition by participants of the skills, highly valued in the market, of the efficient use of various tools for managing social responsibility in a modern organization. Therefore, it is practical, realistic, all-embracing, current and attractive. In a nutshell, this approach can be called PRACA (which means "work" in English):

$$
\text { PRACA }=\text { Practical }+ \text { Realistic }+ \text { All-embracing }+ \text { Current }+ \text { Attractive }
$$

The practicality of the program was assured through the participation, among others, of consultants from the $\mathrm{PwC}$ team for sustainable development and responsible business. A program 
module (40 hours) conducted under their supervision concerns a strategic perspective in practice. Students prepare group projects in which they must take into account such factors as CSR and change management in the organization, identification of social expectations and definition of obligations, analysis of internal and external factors of an organization, CSR strategic plan, methods and tools for CSR implementation, management of environmental and society impact, and social reporting according to GRI. The challenge is therefore to develop practical skills for setting goals, identifying necessary actions and measuring success of its sustainable development within the company.

A realistic dimension of the curriculum is equally important and valued by students. They have an opportunity of a dialogue session with the most experienced CSR managers from companies operating on the Polish market and receiving the highest marks, among others in the Responsible Companies Ranking, prepared by the Business Ethics Centre and $\mathrm{PwC}$ and published annually in Dziennik Gazeta Prawna under the auspices of the Responsible Business Forum. During these meetings (a total of 24 hours), managers present daily challenges, both internal and external, faced by them. The reality of Polish business is specific and the knowledge derived from books, even written by the best authors in the world, should be confronted with the actual experience in the Polish market. CSR is a global idea but it must have a local dimension. Unfortunately in many enterprises, ethics and social responsibility usually begins and ends with the adoption of pleasant-sounding declarations, which are not followed by a genuine will to make significant changes.

In the Polish market, an approach to corporate social responsibility is specific not only because of the obvious historical and social context, but primarily due to domination of this area of company functioning by corporate communication and PR specialists. As a result, all say that they are socially responsible because it sounds nice, but often it does not have much to do with an actual responsibility undertaken. Professional management of business ethics and responsibility requires from future managers or specialists good recognition and accurate diagnosis with respect to both the organization and its environment. Development and implementation of solutions within corporate responsibility is, after all, supposed to strengthen Polish companies and their value and competitiveness on the global market. In addition, it should enable effective collaboration and cooperation of various stakeholders, contributing in this way to a sustainable, harmonious development of economy and assurance of social cohesion. To achieve this, what is really needed is knowledge and understanding of everyday challenges.

The curriculum should be kept current, because both business ethics and social responsibility are all matters that are developing dynamically in all markets. Vigorous discussions, which until recently flourished among economists, management theorists and managers, concerned the purpose of the existence of a company, responsibility for negative social consequences of an economic activity, and the need for voluntary self-regulations. In the face of a serious economic crisis, business leaders are definitely looking for ways for further development that strengthen the role of ethical leadership, take into account the expectations of various groups of stakehol- 
ders in the process of value creation, and also include dynamic changes in further and closer surroundings. The Business Ethics Centre cooperates with top foreign universities in research projects on optimization of responsible business strategies. That experience is being transferred to the curriculum.

This is expressed, among other ways, in the thematic block: innovative strategies to face social challenges (16 hours). University lecturers and cooperating consultants from various companies discuss such issues as strategies for resolving social and environmental conflicts, a strategic dialogue as a basis for business innovation and mutual development, corporate responsibility and social communication responsibility, social entrepreneurship and creating new opportunities for development. In turn, under the CSR theme as a radical innovation (12 hours), the discussion issues are, among others: aspects of entrepreneurship and creativity for sustainable development, full participation in management, organization development through workforce development, standards of responsible management of human resources and CSR innovation development on the global market.

Another dimension of the curriculum is its all-embracing feature. Future managers will increasingly have to take into account entirely new factors in making business decisions. For this, they will need new tools to enable them to move through the network of interdependence. An expanding horizon that must be understood by graduates of such postgraduate studies regards such aspects as the need to build business models based on cross-sectoral cooperation, redefinition of the concept of success in business, the need for binding moral values with everyday business, and adopting a pro-active policy towards the development of the legislative environment through voluntary self-regulation and creating sustainable value.

CSR covers primarily the responsibility of the organization for its impact on the society and the environment. This influence can be both positive and negative. It is about increasing a positive impact and reducing, or eliminating, a negative impact. This requires a holistic approach, identification of social and environmental values and new global challenges. It is not enough to take care of a good reputation, just as it is not enough to take care of working out the biggest profit. Good reputation as well as profit are effects of the proper conduct of business that meets the expectations of all stakeholders.

Therefore, this responsibility is presented from an all-embracing perspective, starting with a thematic unit devoted to ethical dilemmas and decisions ( 24 hours). The lectures and workshops discuss a conflict of interests and responsibility, business lobbying, a praxeological analysis of the action, the ethical infrastructure, designing of ethics programs, justice, freedom and responsibility in a market economy, and confidence in consumer choices. In another part of the course, CSR is presented as a new holistic paradigm of management (28 hours), including the comprehensive management of responsibility, promotion of values in the selection of suppliers, corporate governance, conditions of access to finances, responsible investment and CSR principles in economic policy. 
Within the holistic approach, there is also discussion of the foundation for sustainable development (12 hours), including the perspective of a low carbon economy, environmental management systems, environmental policy instruments in the company, the challenges and priorities of the European environmental policy, quality of life and sustainable development indicators. Another course element is responsible strategies of social marketing and communication (20 hours). This block is run by experienced consultants, covering such areas as the method of measuring social change, social and environmental value of the brand, marketing communications and changes in consumer awareness, CSR and the new interactive communication channels, and social media in CSR.

The last dimension of the curriculum is attractiveness. This is manifested in the selection of instructors, both from academic, business and non-governmental environments, who are genuine leaders of change, capable of convincing others with passion. It becomes more and more clear that it is necessary to make far-reaching systemic changes. Future business leaders can no longer operate upon the same principles as usual. Responsible leadership should address the vision of sustainable development, which is building a dynamic balance in an economic, social and ecological dimension, as well as relationships with current stakeholders and protecting and developing the resources that will be necessary in the future.

This means that the first important feature of a responsible leader is his ability to see the consequences of economic, social and environmental aspects of his business, both the positive and negative ones. The second feature is the ability to build mutually beneficial relationships with stakeholders primarily concerns balancing of conflicting interests through participation and a genuine dialogue. The basis for future business development is the process of agreeing on the rules of conduct between management staff, employees at all levels and other external stakeholders. Based on that understanding, the resulting effect will be a complete commitment by all of them. These are namely stakeholders that assess responsibility as leaders. Finally, the third feature is the ability to see long-term challenges, co-creation of space for an intergenerational dialogue, and imagination allowing acceptance that future generations will also want to fulfil their needs. Responsible leaders should recognize that it is about a wise cooperation for the sake of a new, though still not entirely defined, paradigm of development, leading ultimately to a high quality of life. This is social responsibility. Passion for change in this direction should be effectively transmitted by those who are themselves convinced of the need for systemic changes.

During the discussions that in recent weeks dominated the public discourses in many developed countries, a lot was said about the need for such development that does not lead to exclusion of most citizens. The recent crises does not concern merely financial markets but, above all, the lack of a commonly shared vision of social development. Some commentators argue that the current Polish crisis is to some extent a new reality in which we must learn to live and work in the long run. Turbulence in the financial markets is only a part of the general unstable situation concerning the depletion of natural resources, erosion of energy security, demographic challen- 
ges, social exclusion, a declining access to quality education, and health care, as well as changes in factors affecting the quality of social capital, trust and moral values. A belief that business is based on competition and greed (Wang et al. 2011), and that an invisible hand of the market will itself transform these qualities into social development and prosperity for all, should admittedly be regarded as too naive in the end.

It seems very likely that further development of business will increasingly take into account the principles of responsible management in accordance with the rules of ethics. More and more companies, not only in global markets but also in Poland, are looking for those people who can combine different essential business skills, values and principles. We have painfully convinced ourselves many times that social and moral responsibilities in business cannot be forgotten. Thus, perhaps our graduates, along with other graduates of similar studies all around the world, will begin to provide a strong counterweight to outdated practices and attitudes that lead to subsequent economic disasters.

\section{Final remarks}

Discussion on ethical education of market life participants is concentrated around a few core issues. In the first place, there is the question about the sense of teaching business ethics at a university level. Some people put long-term goals ahead of such teaching and see them as a remedy for scandals and abuses in business; others point out the futility and inefficiency of ethical education. Another controversial issue concerns the content and methods of teaching ethics in business schools. It is worth noting that in this dispute, there are cited arguments of both a theoretical and empirical nature, and the dispute takes place both in the scientific literature and in the media.

Ethical education does not end on the academic stage since it is continued in the form of ethics programs that companies, especially the U.S. ones, introduce in their practices. Systematic studies of these programs, aimed at both managers and the general staff carried out by specialized centres, indicate their effectiveness for both the company and in the broader social context. However, an analysis of their impact on moral attitudes of employees leads to less satisfactory conclusions. A particular challenge, especially in Poland, is the organization of the ethical education in postgraduate studies. The offer of this type of education is addressed at persons who are to play new professional roles such as an ethics spokesman, social responsibility manager, and sustainable development manager. The success of this venture will depend on the one hand on the quality of the offer, and on the other hand refocusing business onto CSR, measured by the level of demand for new professions.

Perception of deficiencies in business ethics education is not equivalent to questioning the sense of this education, but rather constitutes a basis for balanced assessments and realistic demands. Education is needed at both the academic, postgraduate and corporate levels, and all types of 
education should be complementary with respect to each other. They should serve as an important tool for building an ethical infrastructure without which the free market economy cannot function efficiently. However, education cannot be treated as the exclusive remedy for the abuses committed by market players. Limiting abuses requires above all appropriate legal regulations and institutional solutions, but these must be reinforced by appropriate ethical education.

$R$ e $f$ e $r$ e $n$ c e $s$

Aldred J. (2009) The Skeptical Economist: Revealing the Ethics Inside Economics. London: Earthscan.

Andrejczuk M., Bachta W., Gerejczyk K., Kwiatkowska I., Sokołowska J. (2010) Edukacja etyczna w praktyce (Ethical education in practice, in Polish). In: Gasparski W., Rok B., Lewicka-Strzałecka A., Bąk D., Ku obywatelskiej rzeczpospolitej gospodarczej (Towards citizen republic of the economy, in Polish). Warszawa: Wydawnictwo Poltext, pp. 229-236.

Bogle John C. (2009) Dość: Prawdziwe miary bogactwa, biznesu i życia, translated by Anna Gąsior-Niemiec. Warszawa: PTE (orig. Enough: True Measures of Money, Business, and Life, Wiley, Hoboken, NJ, 2009).

Brehm S.S., Brehm J.W. (1981) Psychological reactance: A theory of freedom and control. New York: Academic Press.

Chmielecka E. (2004) opinion presented in: Dyskusja panelowa: Po co ekonomiście filozofia? (Panel discussion: Why does economist need philosophy?, in Polish). In: Kloc K., Chmielecka E. (eds.), Dobre obyczaje w kształceniu akademickim (Good practices in academic education, in Polish) Warszawa.

Dembiński P.H. (2011, Finanse po zawale: Od euforii finansowej do gospodarczego ładu (orig. Finance servante ou finance trompeuse?, in Polish), translated by Łukasz Komuda. Warszawa: Studio Emka.

Fukuyama F. (1997) Zaufanie. Kapitał społeczny a droga do dobrobytu. Warszawa-Wrocław: Wydawnictwo Naukowe PWN (orig. (1995) Trust. The Social Virtues and the Creation of Prosperity. New York: Free Press).

Gasparski W., Lewicka-Strzałecka A. (eds.) (2001) Etyka biznesu jako przedmiot nauczania (Business Ethics as a subject of Teaching, in Polish). Warszawa: WSPiZ.

Gasparski W. (ed.) (2008a) Responsible Management Education. Warszawa: Wydawnictwa Akademickie i Profesjonalne.

Gasparski W. (2008b) Non (nisi) scholae sed vitae discimus - Ku odpowiedzialnemu nauczaniu organizacji i zarządzania (Towards reponsible teaching of the organization and management, in Polish). In: Dietl J., Sapijaszka Z. (eds.), Studia ekonomiczne - czy tylko wiedza i umiejętności? (Economic education: is knowledge and abilities enough?, in Polish). Łódź Fundacja Edukacyjna Przedsiębiorczości, pp. 55-68.

Gasparski W., Rok B., Lewicka-Strzałecka A., Bąk D. (2010) Ku obywatelskiej rzeczpospolitej gospodarczej (Towards citizen republic of the economy, in Polish). Warszawa: Wydawnictwo Poltext.

Jackson C.W. (2008) Bajki w świecie biznesu; Mroczna prawda o fałszowaniu sprawozdań finansowych, translated by Paweł Młodkowski. Warsaw: Wydawnictwo Naukowe PWN (orig.
Business Fairy Tales: Grim Realities of Fictitious Financial Reporting. Tenere of Thomson/South Western, 2006).

Joseph J. (2003) National business ethics survey: How employees view ethics in their organizations Washington DC: Ethics Resource Centre.

Laura R.S. (1983) To educate or to indoctrinate: That is still the question. Educational Philosophy and Theory, Vol. 15, pp. 43-55.

Lewicka-Strzałecka A. (2001) Poznawczy model kształcenia etycznego: studium przypadku. In: Gasparski W., LewickaStrzałecka A. (eds.) (2001) Etyka biznesu jako przedmiot nauczania (Business Ethics as a subject of Teaching, in Polish). Warszawa: WSPiZ.

Lewicka-Strzałecka A. (2010) Spór o kształt etycznej edukacji menedżerów. (Dispute over ethics education for managers, In Polish). Diametros, No. 25, pp. 38-54.

Martell J., CastiňeiraA. (2011) Assessing what It Takes to Earn a Beyond Grey Pinstripes Ranking. In: Swanson D.L., Fisher D.G. (eds.), Towards Assessing Business Ethics Education. North Carolina Charlotte: IAP, pp. 101-131.

Nowak E., Cern K.M. (2008) Ethos w życiu publicznym (Ethos in public life, in Polish). Warszawa: Wydawnictwo Naukowe PWN.

Ossowska M. (2005) Socjologia moralności. Zarys zagadnień, (The sociology of morality: An outline of its problems, in Polish). Warszawa: Wydawnictwo Naukowe PWN.

Pharo P. (2008) Socjologia moralności. Warsaw (orig. Morale et sociologie. Le sens et les valeurs entre nature et culture, Éditions Gallimard, Paris 2004).

Stansbury J., Barry B. (2007) Ethics Programs and the Paradox of Control. Business Ethics Quarterly, Vol. 17, Iss. 2, pp. 239-261.

Swanson D., Fisher, Dann G, (eds.) (2011) Towards Assessing Business Ethics Education. Charlotte, North Carolina: IAP.

Sztylka A. (1999) Jak stawać się humanista (How to become a humanist, in Polish) Warsaw: Stowarzyszenie Oświatowców Polskich.

Trevino L.K., Weaver G.R., Gibson D.G., Toffler B.L. (1999) Managing ethics and legal compliance: What works and what hurts. California Management Review, Vol. 4(2), pp. 131-51.

True S.L., Ferrell O.C. Ferrell L. (2005) Fulfilling Our Obligations: Perspectives on Teaching Business Ethics. Kennesaw State University Press.

Wang L., Malhotra D., Murnighan J.K. (2011) Economics Education and Greed. Learning \& Education, Vol. 10, No. 4, pp. 643-660. 